\title{
Factors Influencing Obesity on School-Aged Children
}

\author{
Soepardi Soedibyo, Tinuk Meilany
}

\begin{abstract}
Abstrak
Anak usia sekolah 6-12 tahun, di kota besar mempunyai aktivitas fisik yang kurang dan gaya hidup yang santai. Fast food dan soft drink yang dikonsumsi mengandung kalori dan protein tinggi berasal dari protein dan karbohidrat. Obesitas mempunyai dampak terhadap tumbuh kembang anak terutama aspek psikososial. Faktor yang turut berperan mendukung terjadinya obesitas pada anak adalah keadaan sosial ekonomi, perilaku dan gaya hidup serta pola makan. Dilakukan penelitian deskriptif analitik secara seksi silang pada murid sekolah dasar di Jakarta, untuk mengidentifikasi faktor yang berperan pada obesitas anak usia sekolah. (Med J Indones 2006; 15:43-54)
\end{abstract}

\begin{abstract}
School-aged children of 6-12 year old in big cities have less physical activities and relax life style. Fast food and soft drink consumed contain high calorie and protein of protein and carbohydrate sources. Obesity has impact on children's growth and development especially on psychosocial aspect. The factors that play a role in supporting the obesity occurrence in children include socio-economic condition, behavior and life style and diet. A cross sectional descriptive-analytic study was conducted on elementary school students in Jakarta, to identify factors that play roles on obesity of school-aged children. (Med J Indones 2006; 15:43-54)
\end{abstract}

Keywords: childhood obesity, weight shape index, body mass index

School-aged children of 6-12 year old indicated growth rate pattern that at first is slow but relatively stable and followed with the growth rate acceleration at adolescent age. In addition to developing and growing phase, the school-aged children also experience life environment shifting, i.e. from house to school environment. The external influence will affect the children's attention and interest, including in diet and nutrition.

Children usually go to school early in the morning so that they usually miss the breakfast. Similarly, they have no time to get lunch at home, so they have to buy out-home snack ${ }^{12}$. The types of snack they prefer easily/usually? are fast food and soft drink, which are available at school canteens. The foods contain high calorie and protein, originated from fat and carbohydrate. Fast food tends to contribute high calorie

Department of Child Health, Faculty of Medicine, University of Indonesia / Dr. Cipto Mangunkusumo Hospital, Jakarta, Indonesia since $40-50 \%$ of which are from fat, containing high level of sodium, but the level of calcium, iron, vitamin A is low.

Parents, teachers and friends of school-aged children have important roles in influencing the children's attitude, behavior, and emotion by influencing eating desire, which commonly have a good eating desire. ${ }^{4}$

By epidemiological measurement, the school-aged children in big cities have less physical activities but in contrary they have relax life style. They are used to spend their spare time by watching television for a long duration, and eat high calorie snack and soft drink, playing computer, play station or other electronic media games, and relatively have infrequent out-door activities such as walking, running and bicycling. Likewise for transportation toward their school, most of them using car than walking or bicycling. ${ }^{5}$ The factors of socio-economic, education and family perception on obesity need consideration, because most of parents still assume that fat children look cute and lovely, which has been interpreted as healthy. ${ }^{6}$ Among older children, especially among girls, they usually try 
to decrease their weight by themselves by inappropriate measures, so that other nutritional problem is emerging, such as anemia, of deficiency of other macronutrient. $^{\text {? }}$

Until now, childhood obesity is still a very difficult problem to overcome because it has multifactor etiologies that have mutual interaction. Obesity has serious impact on child's growth and development, especially on psycho-social aspect. Beside that, childhood obesity is a high-risk factor for adulthood obesity and consequently caused hypertension, cardiovascular, metabolic and orthopedic disorder. ${ }^{8}$ The obesity prevalence in American children tends to increase, from $15 \%$ to almost $30 \%$ and it occurs in elementary school-aged children i.e. from 6-12 years old. Forty percent of childhood obesity may continue up to adolescence, and $75-80 \%$ obesity of that period may continue to adulthood period. ${ }^{9}$ In Indonesia, most of obesity occurs in childhood and adolesence. ${ }^{7}$

The priority in management of obesity is prevention, so that children will not get obese or obesity that has been occurred will not be more severe and they may avoid the complication of hypertension, cardiovascular disorder, hyperlipidemia, fatty liver, diabetes and etc. The therapeutic program of childhood obesity is by comprehensive approach i.e. on child as the obese patient and also on the family. The measures include behavior modification, enhancing activities and diet management.

The objective of such therapy is to prevent the risk of persistent obesity in adulthood period and risk of disease caused by obesity. Until now, the management of childhood obesity has not contributed any satisfied result, because changing behavior is a very hard problem, hence the compliance to therapy is still disappointing.

The above mentioned description of background become principles of defining problems as follows: How is the impact of risk factors which assumed having role on obesity of school-aged children, i.e. in students of elementary school at Elementary School of Tarakanita 5, Islamic Elementary School of Al Azhar 13, Rawamangun and Islamic Elementary School of Kelapa Gading in Special Capital District of Jakarta.

The aim of this study is to recognize factors that might play roles on childhood obesity i.e. effect of family, friends, teachers and obesity in the family.
We expect that this study maybe useful as principles of arranging integrated program regarding all related aspects on management of childhood obesity especially which is related to the environment.

\section{METHODS}

This study was an analytic-descriptive study with cross sectional design, to identify the factors deemed play role on obesity. This study was conducted in 254 elementary students of class I to V, whom has been diagnosed as obesity at Tarakanita 5 Elementary School, Islamic Elementary School of Al Azhar 13, Rawamangun and Islamic Elementary School of Kelapa Gading in North Jakarta. This study was began on May $1^{\text {st }} 2001$ and completed by June $30^{\text {th }} 2001$.

Target population was obese elementary students of class I to V.

Extent population was 254 obese students of class I-V at Tarakanita 5 Elementary School, Islamic Elementary School of Al Azhar 13, Rawamangun and Islamic Elementary School of Kelapa Gading in North Jakarta. The study subjects were obese students of class I-V who meet the study criteria's.

Estimation of sample size that minimally required in this study, which was calculated by Rule of thumb: $10 \times 23=230$. The estimation of drop out probability was $10 \%$; hence the sample size was 254 children.

The inclusion criteria for this study was elementary students with obesity of three Elementary Schools that have been determined in Jakarta, starting from class I to $\mathrm{V}$, and had informed consent from their parents to join the study.

The exclusion criteria were uncooperative patients, having endocrinology disorder or congenital syndrome. Children with any symptoms or attacks during examination that may distract the child's participation in this study, were also excluded.

This study was conducted with permission of parents / custody that has filled the informed consent after receiving explanation about the objective of study, its advantage, and risk for the patient and the probability of side effect. 


\section{The Study Protocol}

1. Screening Test

Screening test of previous study found 631 obese children and of 631 children 254 were studied to recognize factors that play a role on obesity.

\section{Inform consent}

All participants were asked for written permission to their parents or custody on informed consent form.

3. Invitation and dietary form

Direct explanation for the students and mailed explanation for the parents have been conducted. The explanation includes methods of dietary intake notes for 5 days on dietary form. The dietary form was given on (Day)-7 before data collection. On the Day, nutritional expert invited parents of study subject for interview and confirmation of dietary note using food model. If they were not present, then re-agreement was set for the next session, and if they still could not present, then the home visit was conducted.

4. Data collection

a. Physical and anthropometrics examination including: Body weight, Body Height, Upper Arm Circumference (UAC), Skin-Fold Thickness (SFT), waist circumference.

b. Interview for the subject. Questioner fillingup for the presence parents or mailed.

c. Interview of nutritional experts with subject and parents to confirm the dietary notes

5. Interpretation of measurement result

The parameter that has been used to evaluate childhood obesity was body mass index, which was $\geq$ percentile (P) 95 and body mass index against height was $>120 \%$.

\section{Operational Definition}

1. Subject

The subjects of this study were 254 obese students of three Elementary Schools in Jakarta. They were recruited from previous study and appropriate to inclusion and exclusion criteria.

Subjects consist of 157 male and 97 female aged 6 to 12 years. The children age was obtained from birth-date note on questioner and supported by the school. Age was expressed in years; 5 years mean
$5.00-5$ years 11 months 29 days; 6 years $=6.00$ - 6 years 11 months 29 days; 7 years $=7.00-7$ years 11 months 29 days and etc. The year completion was conducted based on calculation and consideration by the formula in table (appendix). The age group was classified into 3 groups 5-7 years, 8-10 years and 11-13 years.

2. Measurement and intervention

Body weight was measured by Detecto scale, which has been standardized before with capacity up to $125 \mathrm{~kg}$. The note was expressed in $\mathrm{kg}$ with decimal (sensitivity to $0.1 \mathrm{~kg}$ ). All of subjects were weighted in bare foot and only use daily school uniform. ${ }^{10}$

Body height was measured by height scale, made of metal, with $1 \mathrm{~mm}$ calibration. The children height was measured in stood upright position and straight forward faces without any shoes. In order to see the result of height measurement, triangle ruler made of wood was placed, upright to the measures, precisely above the head.

The result of Body Height and Body Weight was used to evaluate child's obesity status i.e. body weight index to height is $>120 \%$ and body mass index (BMI) based on age and sex $\geq$ P95.

Upper Arm Circumference was measured by specially-design equipment to measure the upper arm circumference by Child Health Department, Faculty of Medicine, University of Indonesia, Cipto Mangunkusumo Hospital.

The equipment made of plastic that unable to "stretch". The measuring tape was calibrated to $1 \mathrm{~mm}$. Measurement was conducted on half of left upper arm, superior to half olecranon and acromion in suspended hand. ${ }^{11}$ The result was presented in percentile in keeping with age and sex (Appendix)

The skin-fold thickness (SFT) was conducted for triceps, biceps, sub-scapula, and supra-iliac region. Skin-fold thickness measurement was using caliper Holtain, made in Crymmych U.K, which was specially design to measure the skin-fold thickness, with accuracy up to $0.2 \mathrm{~mm}$. SFT of triceps measured was skin fold thickness on half upper left arm between acromion and olecranon (the triceps region) with suspended arm. The measurement of biceps SFT was on frontal arm area, at triceps level, the arm position faced front. 
The measurement of scapula SFT was conducted on lateral inferior of left arm.

The supra-iliac Skin Fold Thickness was measured on mid-axillary's line, slightly superior to the top of left iliac. By analysis of obesity assessment we used Triceps SFT in percentile.

The waist and hip circumference was measured by subject in stand upright position, both of arm besides, stomach relax, the location is at the level of half lowest rib to the top of iliac in midaxillary's line. The measurement of hip circumference was encircling at the level of maximum protuberance of the buttocks. The optimal comparison of waist to hip ratio was not over than 0.8 . That index was related to morbidity risk. If the index is $\geq 0.8$ than the risk of blood pressure elevation, cardiovascular disease and diabetes will also increase. ${ }^{1}$

The blood pressure measurement was conducted in quiet room and the child at quiet condition, using mercury-sphygmomanometer. The cuff measure was justified to age (6-12 years), i.e. 4 inches or $10 \mathrm{~cm}$ and for bigger child 5 inches or $12.5 \mathrm{~cm}$ cuff was provided. The patients were laid prone with straight-arm besides the body. The location for measurement was at right upper arm. Normal blood pressure for children age 6-12 years includes normal systolic $\left(1^{\text {st }}\right.$ Korotkoff sound, the first-heard sound) $\leq 125 \mathrm{~mm} \mathrm{Hg}$ (range 85-125), and normal diastolic $\left(5^{\text {th }}\right.$ Korotkoff, diminished sound) $\leq 70 \mathrm{~mm} \mathrm{Hg}$ (range 50-70). ${ }^{12}$

3. Obesity Classification

Classification of obesity based on BW/BH measurement result and was divided into three categories:

- Mild Obesity / $1^{\text {st }}$ degree $\quad 120-135 \%$

- $\quad$ Moderate Obesity $/ 2^{\text {nd }}$ degree $>135-150 \%$

- Severe Obesity $/ 3^{\text {rd }}$ degree $>150-200 \%$

- Super Obesity (morbid) > $200 \%$

4. Interview and questioner

The necessary additional data was obtained by interviewing subject/child and assigning questioner for the parents.

5. The Energy Intake

Variable of energy intake in this study were diet pattern and eating behavior (includes eating frequency, dining situation, other activities while eating), and obesity-responsiveness. Data was collected from the subject's dietary note, interview and diet analysis. Dietary note was obtained by 5 days - record method and food frequency daily consumption. Estimation about the amount of calorie and protein consumed was using household measurement, and then converted into caloric value. The calorie intake regarded as high intake if it was over 119\% needs, and regarded as normal if it was between $90-119 \%$, and regarded as low if it was below $90 \%{ }^{13}$

6. Energy expenditure.

In this study, we assessed the physical and exercise activities. Daily activities such as sleeping, playing, out-door playing, watching television and computer, transportation to school were evaluated for their type and duration and adjusted with expended calorie amount, and then it was compared to the standard on the appendix. Physical activity was categorized into mild, moderate and severe activity. The exercises at school such as swimming, running, bicycling, badminton, and football were calculated. The energy expenditure was categorized into mild, moderate and severe degree:

Severe : swimming for 30 minutes regularly $3 \mathrm{x} /$ week with an instructor, in-door/ out-door/ school activity (regular exercise $1 \mathrm{x} /$ week)

Moderate : as above mentioned, but the exercise is conducted $1 \mathrm{x} /$ week

Mild : never had any exercise, or occasionally exercise, and irregular without any instructor, including routine exercise at school, but no exercise at home.

\section{The Role Factors}

7.1. Attitude, eating behavior, and responsiveness of the obese children

\subsection{Hereditary / parents' obesity}

Parents who had obesity will be a predisposition for childhood obesity. ${ }^{14}$ The parents' obesity condition was divided into:

- High Risk (80\%) : both of parents were obese

- Moderate Risk (40\%) : one of parents was obese

- Low Risk (14\%) : none of parents was obese

\subsection{Family environment}

Having obese-siblings, parents' education level, income level per capita. 


\section{- Obese-Siblings}

Obese siblings of obese family were divided into: No siblings or had no obese-siblings, had one or more obese-siblings.

- The parents' education level

The parents' education level was obtained from highest education level among parents. The education level was divided into:

- High : academy/ university/ college

- Moderate : Senior High School, Junior High School or at same level

- Low : Elementary School, has not finished the elementary school

- Family income level per capita

By calculating the amount of family income (father, mother and other family member divided with the amount of family burden), income level per capita was assessed. Income level per capita according to the World Development Bank Report 1994, and it was calculated by rupiah amount on March $22^{\text {nd }} 1997$, it was determined by using the criteria of:

$$
\begin{array}{ll}
\text { - } \quad \text { Low } \quad \text { income per capita }<\text { Rp 134,832.-/ } \\
\text { month }
\end{array}
$$

8. The Program of Data Preparation and Presentation We used the statistical program of SPSS version 10 to process and analyze data. The chosen significant level was $\alpha<0.05$. To analyze the role factors, multi-variant test was conducted with multiple logistic regressions.

\section{RESULTS}

\section{The Respondent Characteristics}

The Elementary School of the study respondent was Tarakanita 5 (A) Elementary School, located at Jl. Pemuda No. 6, East jakarta, Islamic Elementary School of Al-Azhar 13, Rawamangun (B) at Jl Sunan Giri, East Jakarta and Islamic Elementary School of Al Azhar Kelapa Gading (C) at Jl. Boulevar Gading
Timur Kelapa Gading, North Jakarta. All of them are private schools, which have permanent school buildings, consist of three floors. The available exercise utilities were basket ball and volley ball court and at the C school there was swimming pool. The education of sport was conducted for 1 hour everytime, including running, gymnastic, basket ball, volley ball, - swimming and the self-defense sport as extra-curriculum course.

Every school had canteen which providing various dietary menu of food and drinks such as various dish of rice, noodles, potatoes, bread, meat ball, snacks, various drinks, soft drinks and candies. At those schools there were also cattering services for students.

The amount of students who meet the study criteria and participate in this study were 254 children, consist of 157 male and 97 female. The participants from School A were 75 children $(29.5 \%)$, consist of 43 male and 32 female. From the School B, there were 97 children (38.2\%), consist of 64 male and 33 female, and from the School C there were 82 children (32.3\%), consist of 50 male and 32 female.

\section{Subject Characteristics}

\section{Age and sex}

Most of subjects consist of 8-10 years of age group (107 children), followed by 5-7 years of age group (74 children) and remaining 11-13 years of age group (73 children). The youngest age was 6 years old and the oldest was 12 years. Mean value of subject age for present study was 8 years, 6 months, with SD 1.50.

\section{Body weight to height index}

The lowest index of body weight to height was $122 \%$ and the highest index was $229 \%$. In male subject, the mean value of body weight to height index was greater than female, i.e. 150.1 compare to 146.7. The mean value of body weight to height index was lowest in the age group of 8-10 years, and then increasing in the age group of 11-13 years. The highest value was for 5-7 years age group. While in female subjects, the lowest value was in 5-7 years age group, then increased on 8-10 years age group and the highest value was on 11-13 years. (Table 1)

\section{Obesity Degree}

Most of obesity degree of 254 students were moderate and severe obesity i.e. 91 children (35.8\%) and 70 
children $(27.5 \%)$ respectively, and the rest? was at super degree for 2 children (0.9\%). Mild obesity? In moderate and severe obesity degree, there were greater amount increased in keeping with greater age, and the greatest was on 8-10 years of age group, then it was decreased on 11-13 years age group. In male, the sequential of greatest amount obesity was severe, moderate, mild and super degree, while in female was moderate, severe and mild obesity degree (Table 2).

\section{Body Mass Index}

Body Mass Index (BMI) is one of measurement to determine the diagnosis of childhood obesity based on age and sex. BMI distribution of study participant started from 18.9 to 39.2 or with $\mathrm{P}_{95}$ to $>\mathrm{P}_{97}$. The greatest number $(73.2 \%)$ of both male or female were on percentile $>\mathrm{P}_{97}$, and increased in keeping with greater age, but it decreased on 11-13 years group (Table 3)

Table 1. Distribution of mean value of body weight to height index based on sex and age group

\begin{tabular}{|c|c|c|c|c|c|c|c|c|c|}
\hline \multirow{3}{*}{$\begin{array}{c}\text { Age } \\
\text { Group } \\
\text { (yr) }\end{array}$} & \multicolumn{6}{|c|}{ Body weight to height index } & \multirow{2}{*}{\multicolumn{3}{|c|}{ Amount }} \\
\hline & & Male & & & Female & & & & \\
\hline & Mean & (SD) & $\mathrm{n}$ & Mean & (SD) & $\mathrm{n}$ & Mean & (SD) & $\mathrm{n}$ \\
\hline $5-7$ & 151.45 & $(24.88)$ & 4 & 138.54 & $(14.21)$ & 28 & 146.57 & $(22.27)$ & 74 \\
\hline $8-10$ & 149.24 & $(15.71)$ & 73 & 146.65 & $(18.26)$ & 34 & 148.61 & $(16.52)$ & 107 \\
\hline $11-13$ & 150.14 & (19.49) & 38 & 153.33 & (17.06) & 35 & 151.67 & $(18.31)$ & 73 \\
\hline Total & 150.1 & (19.58) & 157 & 146.7 & (17.61) & 97 & 148,81 & (18.89) & 254 \\
\hline
\end{tabular}

Notes : The index of BW / BH is \% BW compare to ideal BW consistent with $\mathrm{BH}$ :

$\mathrm{BW} / \mathrm{BH}$ - age group, Pearson correlation 0.103 , with $\mathrm{p} 0.05$;

$\mathrm{BW} / \mathrm{BH}-\mathrm{sex}$, Pearson correlation 0.087 with $\mathrm{p}=0.08$.

Table 2. The amount of subject according to obesity degree on the age group and sex

\begin{tabular}{|c|c|c|c|c|c|c|c|c|c|c|c|c|c|c|c|}
\hline \multirow{3}{*}{$\begin{array}{c}\text { Age } \\
\text { (years) }\end{array}$} & \multirow{2}{*}{\multicolumn{3}{|c|}{$\mathrm{n}$}} & \multicolumn{12}{|c|}{$\mathrm{BW} / \mathrm{BH}$} \\
\hline & & & & \multicolumn{3}{|c|}{ Mild } & \multicolumn{3}{|c|}{ Moderate } & \multicolumn{3}{|c|}{ Severe } & \multicolumn{3}{|c|}{ Super } \\
\hline & $M$ & $\mathrm{~F}$ & $\mathrm{~T}$ & $M$ & $\mathrm{~F}$ & $\mathrm{~T}$ & $\mathrm{M}$ & $\mathrm{F}$ & $\mathrm{T}$ & $M$ & $\mathrm{~F}$ & $\mathrm{~T}$ & $\mathrm{M}$ & $\mathrm{F}$ & $\mathrm{T}$ \\
\hline $5-7$ & 46 & 28 & 74 & 15 & 16 & 31 & 14 & 7 & 21 & 16 & 5 & 21 & 1 & 0 & 1 \\
\hline $8-10$ & 73 & 34 & 107 & 14 & 10 & 24 & 32 & 12 & 44 & 27 & 12 & 39 & 0 & 0 & 0 \\
\hline $11-13$ & 38 & 35 & 73 & 12 & 3 & 15 & 10 & 16 & 26 & 15 & 16 & 31 & 1 & 0 & 1 \\
\hline Total & 157 & 97 & 254 & 41 & 29 & 70 & 56 & 35 & 91 & 58 & 33 & 91 & 2 & 0 & 2 \\
\hline
\end{tabular}

Notes: BW, body weight $(\mathrm{kg})$; BH, body height $(\mathrm{m}) ; \mathrm{M}$ (male ); F(female); T(total); $\mathrm{n}=$ amount. BW/BH = obesity degree, in 4 level: Mi (mild): $>120-35 \%$, Mo (Moderate): $>135-150 \%$, Se (severe): $>150-200 \%$, Sp (super) $>200 \%$. Correlation: obesity degree-age $x^{2}$ $13.34 d f=6 \quad p=0.04$. Obesity degree- male sex: $x^{2}=7.07 \quad \mathrm{df}=6, \mathrm{p}=0.32 ;$ Female: $\mathrm{x}^{2}=17.7 \mathrm{df}=4 \mathrm{p}=0.001$

Table 3. The number of obesity students according to body mass index against age group and sex

\begin{tabular}{|c|c|c|c|c|c|c|c|c|c|c|c|c|c|c|c|}
\hline \multirow{3}{*}{$\begin{array}{l}\text { Age } \\
\text { (year) }\end{array}$} & \multicolumn{12}{|c|}{$\mathrm{BWBH}^{2}$} & \multirow{2}{*}{\multicolumn{3}{|c|}{$\mathrm{n}$}} \\
\hline & \multicolumn{3}{|c|}{$\mathrm{P}_{95}$} & \multicolumn{3}{|c|}{$>\mathrm{P}_{95^{-}}<\mathrm{P}_{97}$} & \multicolumn{3}{|c|}{$\mathrm{P}_{97}$} & \multicolumn{3}{|c|}{$>\mathrm{P}_{97}$} & & & \\
\hline & $\mathrm{M}$ & $\mathrm{F}$ & $\mathrm{T}$ & $\mathrm{M}$ & $\mathrm{F}$ & $\mathrm{T}$ & M & $\mathrm{F}$ & $\mathrm{T}$ & $\mathrm{M}$ & $\mathrm{F}$ & $\mathrm{T}$ & $\mathrm{M}$ & $\mathrm{F}$ & $\mathrm{T}$ \\
\hline $5-7$ & 1 & 1 & 2 & 5 & 7 & 13 & 1 & 2 & 3 & 39 & 20 & 59 & 46 & 28 & 74 \\
\hline $8-10$ & 4 & 1 & 5 & 7 & 8 & 17 & 1 & 1 & 2 & 61 & 24 & 85 & 73 & 34 & 107 \\
\hline $11-13$ & 4 & 2 & 6 & 9 & 11 & 24 & 3 & 2 & 5 & 22 & 20 & 42 & 38 & 35 & 73 \\
\hline Total & 9 & 4 & 14 & 21 & 24 & 54 & 5 & 5 & 10 & 122 & 64 & 186 & 157 & 97 & 254 \\
\hline
\end{tabular}

$\mathrm{BW} / \mathrm{BH}^{2}$ or BMI (body mass index) in percentile, $\mathrm{BW}$, body weight $(\mathrm{kg}) ; \mathrm{BH}$, body height $(\mathrm{m}) ; \mathrm{M}$ (male); $\mathrm{F}(\mathrm{female}) ; \mathrm{T}(\mathrm{total})$; $\mathrm{n}=$ amount. Correlation of BMI - age group: $x^{2} 13.87 d f=6 p=0.03$; In male, $x^{2} 12.65 d f 6 \mathrm{p} 0.049$; In female $x^{2} 2.75 d f 6 \mathrm{p} 0.84$. 


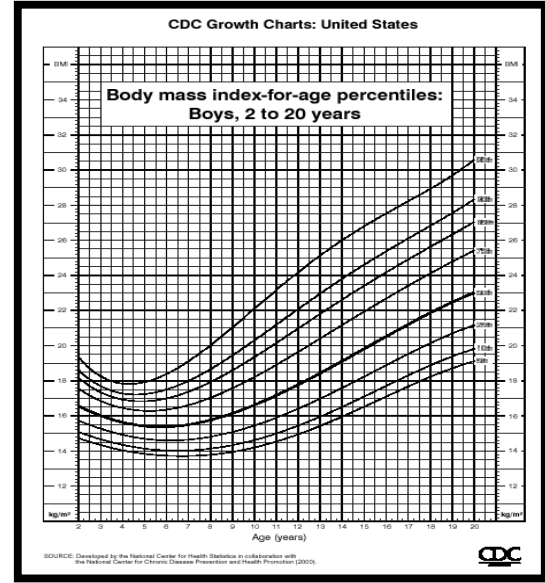

Figure 1. BMI distribution of female

\section{Blood pressure}

The result of systolic blood pressure examination $\leq$ P95 was $94.1 \%(239 / 254)$ and > P95 was 5.9\% (15/254). Diastolic blood pressure was $80.3 \%(204 / 254)$ on $\leq$ P95 and $19.7 \%(50 / 254)$ on > P95. The correlation of blood pressure elevation and BMI was not significant neither in systolic nor diastolic blood pressure. (table 4 and 5).

Table 4. The distribution of systolic blood pressure based on BMI

\begin{tabular}{|c|c|c|c|c|c|c|c|c|c|c|}
\hline \multirow{3}{*}{ SBP } & \multicolumn{8}{|c|}{ BMI } & \multirow{2}{*}{\multicolumn{2}{|c|}{ Total }} \\
\hline & \multicolumn{2}{|c|}{ P95 } & \multicolumn{2}{|c|}{ > P95-97 } & \multicolumn{2}{|c|}{ P97 } & \multicolumn{2}{|c|}{ > P97 } & & \\
\hline & $\mathrm{n}$ & $\%$ & $\mathrm{n}$ & $\%$ & $\mathrm{n}$ & $\%$ & $\mathrm{n}$ & $\%$ & $\mathrm{n}$ & $\%$ \\
\hline$\leq \mathrm{P} 95$ & 13 & 5 & 45 & 17.7 & 9 & 3.5 & 172 & 67.7 & 239 & 94 \\
\hline$>$ P 95 & 0 & 0 & 1 & 0.4 & 1 & 0.4 & 13 & 5 & 15 & 6 \\
\hline total & 13 & 5 & 46 & 18.1 & 10 & 3.9 & 185 & 72.7 & 254 & 100 \\
\hline
\end{tabular}

SBP, systolic blood pressure $X^{2}=2.69 \quad \mathrm{df}=3 \quad \mathrm{P}=0.44$

Table 5. The distribution of diastolic blood pressure based on BMI

\begin{tabular}{|c|c|c|c|c|c|c|c|c|c|c|}
\hline \multirow{3}{*}{ DBP } & \multicolumn{8}{|c|}{ BMI } & \multirow{2}{*}{\multicolumn{2}{|c|}{ Amount }} \\
\hline & \multicolumn{2}{|c|}{ P95 } & \multicolumn{2}{|c|}{$>$ P95-97 } & \multicolumn{2}{|c|}{ P97 } & \multicolumn{2}{|c|}{ > P97 } & & \\
\hline & $\mathrm{n}$ & $\%$ & $\mathrm{n}$ & $\%$ & $\mathrm{n}$ & $\%$ & $\mathrm{n}$ & $\%$ & $\mathrm{n}$ & $\%$ \\
\hline$\leq \mathrm{P} 95$ & 11 & 4.2 & 42 & 16.5 & 9 & 3.5 & 142 & 35.5 & 204 & 80.3 \\
\hline > P 95 & 2 & 0.8 & 4 & 1.6 & 1 & 0.4 & 43 & 16.9 & 50 & 19.7 \\
\hline Total & 13 & 5 & 46 & 18.1 & 10 & 3.9 & 185 & 52.4 & 254 & 100 \\
\hline
\end{tabular}

DBP, diastolic blood pressure $\mathrm{X}^{2}=5.74 \mathrm{df}=3 \mathrm{P}=0.13$

\section{Energy Intake}

The mean energy intake of subject was 2272 calorie. Male subjects had energy intake exceed normal needs, and it was double amount of female subjects, the greatest number was on 8-10 years age group. Female

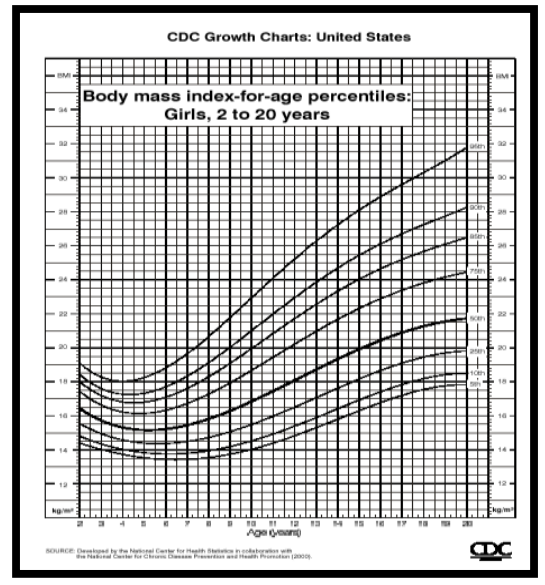

Figure 2. BMI distribution of male

subjects with high energy intake was decreasing in keeping with greater number. In contrast, they consumed food with less calorie of normal needs, and the number was increasing in keeping with greater age. (Table 6)

Table 6. Caloric input of obesity students based on age group and sex

\begin{tabular}{lcccccccccc}
\hline \multirow{2}{*}{$\begin{array}{c}\text { Age } \\
\text { Group }\end{array}$} & \multicolumn{7}{c}{ High } & \multicolumn{7}{c}{ Appropriate } & \multicolumn{2}{c}{ Low } & Total \\
& \cline { 2 - 8 } & amount \\
\cline { 2 - 9 } & M & F & T & M & F & T & M & F & T & \\
\hline $5-7$ & 36 & 19 & 55 & 4 & 4 & 8 & 6 & 5 & 11 & 74 \\
$8-10$ & 51 & 18 & 69 & 22 & 9 & 31 & 0 & 7 & 7 & 107 \\
$11-13$ & 28 & 12 & 40 & 9 & 14 & 23 & 1 & 9 & 10 & 73 \\
\hline Total & 115 & 49 & 164 & 35 & 27 & 62 & 7 & 21 & 28 & 254 \\
\hline
\end{tabular}

Notes: high energy intake: $\geq 120 \%$, appropriate: $90-119 \%$, Low $<90 \%$ of needs, consistent with daily recommended nutritional value / Widya Karya Nasional Pangan dan Gizi 1998

There was greater number of male subjects who consumed diet, which containing protein beyond normal needs compared to female subjects, and the number of subject consuming higher protein greater than appropriate or less than normal protein (Table 7).

Table 7. The subject's protein intake based on age group and sex

\begin{tabular}{|c|c|c|c|c|c|c|c|c|c|c|}
\hline \multirow{3}{*}{$\begin{array}{l}\text { Age } \\
\text { Group }\end{array}$} & \multicolumn{9}{|c|}{ Protein intake } & \multirow{3}{*}{$\begin{array}{c}\text { Total } \\
\text { amount }\end{array}$} \\
\hline & \multicolumn{3}{|c|}{ High } & \multicolumn{3}{|c|}{ Appropriate } & \multicolumn{3}{|c|}{ Low } & \\
\hline & $\mathrm{M}$ & $\mathrm{F}$ & $\mathrm{T}$ & $\mathrm{M}$ & $\mathrm{F}$ & $\mathrm{T}$ & $\mathrm{M}$ & $\mathrm{F}$ & $\mathrm{T}$ & \\
\hline $5-7$ & 41 & 23 & 64 & 4 & 2 & 6 & 1 & 3 & 4 & 74 \\
\hline $8-10$ & 55 & 17 & 72 & 13 & 8 & 21 & 5 & 9 & 14 & 107 \\
\hline $11-13$ & 25 & 12 & 37 & 11 & 11 & 22 & 2 & 12 & 14 & 73 \\
\hline Total & 121 & 52 & 173 & 28 & 21 & 49 & 6 & 24 & 30 & 254 \\
\hline
\end{tabular}

Notes: normal protein based on daily recommended nutritional value, Widyakarya Nasional Pangan dan Gizi 1998. (Appendix) 
The recommended diet composition consists of 3 groups i.e. carbohydrate, protein and lipid. The subject's diet intake consists of: carbohydrate with range of $23-72 \%$ and mean value of $52.5 \%$; protein with range of $7-31 \%$ and mean value of $11.8 \%$; lipid with range of $17-52 \%$ and mean value of $35.03 \%$.

The composition of subject's lipid intake, which was $>30 \%$ greater than the $\leq 30 \%$, were 183 compared to 71 subject. The chi square test on correlation of lipid intake percentage and obesity degree was not significant $(\mathrm{p}=0.71)$

\section{Physical Activity}

$50 \%$ of subject (127/254) had light physical-activity, $39.4 \%$ (100/254) had moderate physical activity and $10.6 \%(27 / 254)$ subject had heavy physical activity.

\section{The correlation of physical activity and obesity degree}

The subject who had heavy physical activity was decreasing in keeping with greater obesity degree, and in contrast, the subject with light physical activity was increasing in keeping with greater obestiy degree. The correlation was statistically significant $(\mathrm{p}<0.05)$ (table 8).

Table 8 . Physical activity level based on obesity degree

\begin{tabular}{|c|c|c|c|c|c|c|c|c|c|c|}
\hline \multirow{3}{*}{$\begin{array}{c}\text { Activity } \\
\text { level }\end{array}$} & \multicolumn{8}{|c|}{ Obesity Degree } & \multirow{2}{*}{\multicolumn{2}{|c|}{ Total }} \\
\hline & \multicolumn{2}{|c|}{ Mild } & \multicolumn{2}{|c|}{ Moderate } & \multicolumn{2}{|c|}{ Severe } & \multicolumn{2}{|c|}{ Super } & & \\
\hline & $\mathrm{n}$ & $\%$ & $\mathrm{n}$ & $\%$ & $\mathrm{n}$ & $\%$ & $\mathrm{n}$ & $\%$ & $\mathrm{n}$ & $\%$ \\
\hline Heavy & 10 & 14.2 & 10 & 10.9 & 7 & 7.7 & 0 & 0 & 27 & 10.6 \\
\hline Appropriate & 29 & 41.4 & 38 & 41.8 & 32 & 35.2 & 1 & 50 & 100 & 39.4 \\
\hline Light & 31 & 44.4 & 43 & 47.3 & 52 & 57.1 & 1 & 50 & 127 & 50 \\
\hline Total & 70 & 27.6 & 91 & 35.8 & 91 & 35.8 & 2 & 0.8 & 254 & 100 \\
\hline $\mathrm{X} 2=3.826$ & & & & & & $p$ & & & & \\
\hline
\end{tabular}

\section{The Influencing Factors}

\section{The subject's attitude and behavior}

Most of the subjects (55.1\%) had incorrect perception about their obesity or other, and about $44.9 \%$ had correct perception. The correct perception deemed obesity harm the health. (Table 9)

Table 9. The subject's perception on obesity

\begin{tabular}{lcc}
\hline Perception & Amount & $\%$ \\
\hline Correct & 114 & 44.9 \\
Incorrect & 140 & 55.1 \\
\hline Total & 254 & 100 \\
\hline
\end{tabular}

\section{Eating behavior}

$70.5 \%$ subjects had bad behavior on their obesity, and $29.5 \%$ had good behavior. Bad behavior was regarding no effort of behavior of decreasing body weight such as over-eating, extra-diet, having snack while watching television. (Table 10).

Table 10. The subject's eating behavior

\begin{tabular}{ccc}
\hline Eating behavior & Amount & $\%$ \\
\hline Good & 75 & 29.5 \\
Bad & 179 & 70.5 \\
\hline Total & 254 & 100 \\
\hline
\end{tabular}

There was greater number of bad eating behavior in 1 , 2,3 , and 4 obesity degree compared to good eating behavior. The subject with $4^{\text {th }}$ obesity degree had bad eating behavior. The eating behavior was significantly correlated to the obesity degree $(\mathrm{p}=0.038)$, i.e the greater obesity degree, the worse eating-behavior. (Table 11)

Table 11. The correlation of obesity degree and eating behavior

\begin{tabular}{lcc}
\hline \multirow{2}{*}{ Obesity Degree } & \multicolumn{2}{c}{ Eating behavior } \\
\cline { 2 - 3 } & Good $\{\mathrm{n}(\%)\}$ & $\operatorname{Bad}\{\mathrm{n}(\%)\}$ \\
\hline Mild & 14 & 56 \\
Moderate & 33 & 58 \\
Severe & 28 & 63 \\
Super & 0 & 2 \\
\hline Amount & 75 & 179 \\
\hline
\end{tabular}

Chi-square test of correlation between obesity degree and eating behavior: $\mathrm{X}^{2}=8.436 \mathrm{df}=3 \quad \mathrm{p}=0.038$

In present study, $55.9 \%$ of subjects still had bad responsiveness to overcome their obesity, such as some of them just occasionally or even never reduce their eating portion, extra-diet and never had any physical exercise. (Table 12).

Table 12. The subject's self-responsiveness of overcoming the obesity

\begin{tabular}{lcc}
\hline Self-responsiveness of obesity & Amount & $\%$ \\
\hline Good & 112 & 44.1 \\
Bad & 142 & 55.9 \\
\hline Total & 254 & 100 \\
\hline
\end{tabular}

Subjects who had bad responsiveness were students of 6-10 years old, and decreased in keeping with greater age. 
Table 13. The Correlation of responsiveness level and age

\begin{tabular}{lccc}
\hline \multirow{2}{*}{ Age } & \multicolumn{2}{c}{ Responsiveness level } & \multirow{2}{*}{ Amount } \\
\cline { 2 - 3 } & Bad & Good & \\
\hline $6.00-6.999$ & 10 & 6 & 16 \\
$7.00-7.999$ & 35 & 23 & 58 \\
$8.00-8.999$ & 32 & 26 & 58 \\
$9.00-9.999$ & 30 & 20 & 49 \\
$10.00-10.999$ & 21 & 16 & 38 \\
$11.00-11.999$ & 13 & 21 & 34 \\
$12.00-12.999$ & 1 & & 1 \\
\hline & 142 & 112 & 254 \\
\hline
\end{tabular}

Note: Bad responsiveness level if the score $\leq 5$, good responsiveness level $>5$

\section{The factor of family obesity}

\section{A. Parents}

None of parents of $42.1 \%$ had any obesity, $32.7 \%$ subjects had both of parents with obesity and the remainder $25.2 \%$ had one of parents with obesity. (Table 14 ).

Table 14. Parents' obesity

\begin{tabular}{lcc}
\hline \multicolumn{1}{c}{ Parents' Obesity } & Amount & $\%$ \\
\hline Both of parents & 83 & 32.7 \\
One of parents & 64 & 25.2 \\
None of parents had obesity & 107 & 42.1 \\
\hline Total & 254 & 100 \\
\hline
\end{tabular}

\section{B. Siblings}

184 of 254 subjects had sibling with obesity, and the remainder had no obesity or had no sibling (Table 15)

Table 15. The Obesity in participant's sibling

\begin{tabular}{lcl}
\hline The sibling's obesity & Jumlah & $\%$ \\
\hline Had siblings with obesity & 184 & 72.5 \\
$\begin{array}{l}\text { Had no siblings with obesity or } \\
\text { single-child }\end{array}$ & 70 & 27.5 \\
\hline Total & 254 & 100 \\
\hline
\end{tabular}

\section{The parents' influence}

$33.1 \%$ subject got bad influence of obesity from their parents, $48 \%$ had moderate influence and $18.9 \%$ had good influence. (Table 16).

Table 16. The parents' influence

\begin{tabular}{lcc}
\hline The influence level & Amount & $\%$ \\
\hline Good & 48 & 18.9 \\
Moderate & 122 & 48 \\
Bad & 84 & 33.1 \\
\hline Total & 254 & 100 \\
\hline
\end{tabular}

\section{The parents' education level}

There was $74.5 \%$ subject's parents with high education level ( $\geq$ Bachelor), 25.5\% moderate education level and there was no subject's parents with low education level (completed Elementary School or uncompleted Elementary School)

Table 17. The parents' education level factor

\begin{tabular}{lcc}
\hline Education level & Amount & $\%$ \\
\hline High & 190 & 74.5 \\
Moderate & 64 & 25.5 \\
Low & 0 & 0 \\
\hline Total & 254 & 100 \\
\hline
\end{tabular}

The parents' income level

There were $51.8 \%$ subject's parents with high-income level (> Rp1,664,737,-), 48.2\% with moderate-income level, and none of them had low-income level $(<\mathrm{Rp}$ 134,832.-) (Table 18)

Table 18. Factor of parents' income level

\begin{tabular}{lcc}
\hline Income level per capita & Amount & $\%$ \\
\hline High & 132 & 51.8 \\
Moderate & 122 & 48.2 \\
Low & 0 & 0 \\
\hline Total & 254 & 100 \\
\hline
\end{tabular}

The deemed factors of obesity that were involved in the management of subject's obesity were tested by uni-variant and multivariate test. We found that parents' obesity risk, sibling's obesity, parents' high education and income level were significantly correlated to BMI.

While the parents' influence, obesity perception, obesity responsiveness and eating behavior were not statistically significant, $\mathrm{p}>0.005$.

Table 19. Factors on obesity against BMI

\begin{tabular}{lcccccc}
\hline \multirow{2}{*}{\multicolumn{1}{c}{ Factors }} & \multicolumn{3}{c}{ Univariate } & \multicolumn{3}{c}{ Multivariate } \\
\cline { 2 - 7 } & $\mathrm{X} 2$ & $\mathrm{Df}$ & $\mathrm{p}$ & $\mathrm{X} 2$ & $\mathrm{df}$ & $\mathrm{P}$ \\
\hline Parents' obesity risk & 12.583 & 3 & 0.000 & 12.583 & 3 & 0.000 \\
Sibling's obesity risk & 0.896 & 3 & 0.003 & 0.896 & 3 & 0.003 \\
Parents' influence & 0.334 & 3 & 0.573 & 0.334 & 3 & 0.573 \\
Parents' education level & 1.091 & 3 & 0.001 & 1.091 & 3 & 0.001 \\
Parents' income level & 1.108 & 3 & 0.004 & 1.108 & 3 & 0.004 \\
Obesity perception & 0.118 & 3 & 0.703 & 0.118 & 3 & 0.703 \\
Therapeutic & 0.425 & 3 & 0.161 & 0.425 & 3 & 0.161 \\
responsiveness & & & & & & \\
Eating behavior & 3.209 & 3 & 0.928 & 3.209 & 3 & 0.92 \\
\hline
\end{tabular}




\section{DISCUSSION}

The present study found greater number of obese male students compared to the female with comparison of 157 : 97. This result was different from SUSENAS result, i.e. obesity occurred more in female students. SUSENAS of 1989 found $4.6 \%$ obesity prevalence of male students and $5.9 \%$ in female students, while in 1992 there was increased number of male students $6.3 \%$ and female students $8 \% .^{15}$

The age of subjects in present study was ranging from 6 to 12 years old, with mean age value was 8 years and 6 months. This was consistent with the prevalence of obesity either in America ${ }^{1-3}$ or Indonesia, and it relatively occurred in children and adolescence. ${ }^{3}$ If we consider the school building of the studied elementary school, all of those private schools were represented students with middle-class to high-class socio economical status. Every school had canteen providing various dietary menu, such as rice, noodle, potato, various dishes, bread, meat ball, snack, and various drinks, soft drink and candies. This was consistent with the fact that most of the students prefer to having snack ${ }^{5,6}$ The selected diet was fast food and soft drink, which were available at the school canteen. Those diet contained high protein and calorie, which the calorie derived from lipid and carbohydrate. Fast food tends to give high calorie because $40-50 \%$ derived from lipid, has high sodium level, but low calcium, iron and vitamin $\mathrm{A} \mathrm{level}^{7}$ Tabel 1 indicated increasing obesity prevalence consistent with increasing age. Table 2 indicated that the most abundant obesity degree were moderate and severe degree, i.e. 91 children (35.8\%) and 70 children $(27.5 \%)$ respectively, and the remainder with super degree of 2 children $(0.9 \%)$. In male subject, the sequential of greatest amount obesity was severe, moderate, mild and super degree, while in female was moderate, severe and mild obesity degree The diagnosis of obesity in present study was based on Body Mass Index (BMI), BMI distribution, greatest participant number $(73.2 \%)$ in percentile $>\mathrm{P}_{97}$. (Table 3 ). While if it was correlated to blood pressure elevation, then there was no significant result between BMI and systolic or diastolic blood pressure, as indicated by table 4. It is very important because the long-period complication might occur related to the obesity such as hypertension, hemodynamic disorder, coronary heart disease risk. ${ }^{19,20}$

The present study indicated that the subject's food intake had such composition: carbohydrate ranged from
$23-72 \%$ and mean value of $52.5 \%$, protein ranged from $7-31 \%$ with the mean value of $11.8 \%$; lipid ranged from $17-52 \%$ with the mean value of $35.03 \%$. These were not consistent with the recommended balanced diet of 50\% carbohydrate, $30 \%$ lipid, and adequate protein for normal development and growth $(20 \%) .^{16,17}$ Based on other literature, the recommended diet is food intake with low carbohydrate contain (48\% of total energy), decreasing lipid intake (30\% of total energy), with saturated lipid (10\% of total energy), cholesterol below 300mg per day, and added high fiber diet. ${ }^{18}$ The composition of subject's lipid intake, which was greater for $>30 \%$ compared to the $\leq 30 \%$, i.e. 183 compared to 71 subjects.

The chi-square test on correlation between percentage of lipid intake and obesity degree was not significant $(p=0.71)$. This was not consistent with the literature that one of obesity etiology is high calorie with 40$50 \%$ of it derived from lipid. ${ }^{7}$

Fifty percent of subject (127/254) had light physicalactivity, 39.4\% (100/254) had moderate physical activity and $10.6 \%$ (27/254) subject had heavy physical activity. The subjects who had heavy physical activity were decreasing in keeping with greater obesity degree, and in contrast, the subjects with light physical activity were increasing in keeping with greater obestiy degree. The correlation was statistically significant $(\mathrm{p}<0.05)$ (table 8). Other factors that also influenced obesity, such as incorrect obesity perception either to themselves or other $(55.1 \%)$ and only $44.9 \%$ regard obesity harmful for health as described in Table 9.

Other factor was subject's behavior to their obesity, that $70.5 \%$ subjects had bad behavior on their obesity, and $29.5 \%$ had good behavior. Bad behavior was regarding no effort of behavior of decreasing body weight such as over-eating, extra-diet, having snack while watching television. (Table 10).

Data indicated that children's physical activity tends to reduce, they had more in-door activity than outdoor activity, they watched a lot of television program, including children program, apart from diet advertisement which influenced enhanced consumption of sweet diets or 'extra-diet'.

In contrast, watching television will decrease activity and energy expenditure, because they seldom had walking, bicycling or up-down stair movement. ${ }^{17,18}$ 
Table 12 indicated that $55.9 \%$ of subject still had bad responsiveness to overcome their obesity, such as some of them just occasionally or even never reduce their eating portion, extra-diet and never had any physical exercise.

Subjects who had bad responsiveness were students of 6-10 years old, and decreased in keeping with greater age. From table 14 we found that only $32.7 \%$ subjects had both of parents with obesity and $25.2 \%$ had one of parents with obesity, while $42.1 \%$ subjects had none of parents with obesity.

Based on literature, we found that genetic factor plays important role as parental fatness, obese children usually came from obese family. If both of parents were obese, approximately $80 \%$ of their children will become obese. If one of parents, then the obesity occurrence is $40 \%$ and if none of parents was obese then the occurrence decreases to $14 \%$. The increased risk of obesity might be caused by genetic or environment factor in the family. ${ }^{20,21}$

Considering the present percentage, environment factor in family also has important role beside the genetic factor causing childhood obesity. From table 15 , we found that 184 of 254 subjects had sibling with obesity, and the remainder had no obesity or had no sibling. Thirty-three point one percent of subjects got bad influence of obesity from their parents, $48 \%$ had moderate influence and $18.9 \%$ had good influence as noted on table 16 . There was $74.5 \%$ subject's parents with high education level ( $\geq$ Bachelor), 25.5\% moderate education level and there was no subject's parents with low education level (completed Elementary School or uncompleted Elementary School). There were $51.8 \%$ subject's parents with high-income level (> Rp. 1,664,737,-), 48.2\% with moderate-income level, and none of them had low-income level ( $<$ Rp 134,832.-) (Table 18).

Those facts were consistent with literature which mentioned the factors supporting obesity occurrence are social, economic, ethnical and psychological factors. The alteration of knowledge, attitude, behavior, life style, diet pattern, and increment of income level, may affect the alteration type of food selection and its amount of consumption. ${ }^{22}$

For example, recently, in big cities we found the double-role mothers i.e. as housewife and carrier woman or working woman. This condition affected the diet pattern and the type of consumed diet. The frequency of out-home dining tends to increase, primarily by school-aged children. The available snack frequently selected by parents or children is fast food or junk food.

The deemed factors of obesity that were involved in the management of subject's obesity were tested by univariate and multivariate test. We found that parents' obesity risk, sibling's obesity, parents' high education and income level were significantly correlated to BMI. While the parents influence, obesity perception, obesity responsiveness and eating behavior were not statistically significant, $\mathrm{p}>0.005$.

\section{CONCLUSION}

Most of obese students with higher than standard energy intake were male students, and it was increasing consistent with greater age. In contrast, high-energy intake of female was decreasing consistent with greater age. The high protein intake in subject was consistent with high-energy intake.

Thirty percent of obese students had high adolescence obesity risk (both of parents were obese), and 25\% had moderate risk (one of parents was obese). Most of obese students $(70 \%)$ have obese siblings. Obese students have quite significant factors supporting more obesity and contrary, as negative factors of obesity treatment. Among them there was bad environment influence, i.e. obesity in the family, such as parents and siblings and lack of activity. The positive factors on obesity were parents' education level related to occupation and middle-class to highclass socio economic status.

\section{REFERENCES}

1. Polnay L, Hull D, editor. Eating well. School-age child. Community paediatrics. Tokyo: Churchill Livingstone; 1993.

2. Fong H. Fastfood: a matter of balance. In: Samsudin, Nasar SS, Sjarif DR, editors. Masalah gizi ganda dan tumbuh kembang anak. Jakarta; Bina Rupa Aksara 1995: 114- 8.

3. Nelson WE, Behrman RE, Kliegman RM, Arvin AM, editors. Early school years. Textbook of Pediatrics. Tokyo: WB Saunders Co; 1996.

4. Weaver KA, Piatek A. Childhood obesity. In: Samour PQ, Helm KK, Lang CE, editors. Handbook of Pediatric Nutrition. 2nd ed. Maryland: Aspen Publishers Inc; 1999. p. 173-89.

5. Epstein LH. New developments in childhood obesity. In: Stunkard AJ, Wadden TA, edtiors. Obesity theory and 
therapy. 2 nd ed. New York: Raven Press Ltd; 1993. p. 301-11.

6. Alemzadeh R, Lifshitz F. Childhood obesity. In: Lifhitz F, editor. Pediatric endocrinology. New York: Marcel Deccer, Inc; 1996. h. 753-74.

7. Samsudin, Soedibjo S. Penilaian keadaan gizi dan pertumbuhan: cara, kegunaan, dan keterbatasan. In: Samsudin, Nasar SS, Sjarif DR, editors. Masalah gizi ganda dan tumbuh kembang anak. Proceedings of the PKB IKA XXXV. Jakarta; 1995 .p. 49-58.

8. Rimm AA, Hartz AJ, Fischer ME. A weight shape index for assesing risk of disease. J C Clin Epidemiol 1988; 41 (5) : 458-65.

9. Berkowitz RI. Obesity in childhood and adolescence. In: Walker WA, Watkins JB, editors. Nutrion in Pediatrics. Basic science and clinical applications. London: BC Decker inc; 1997. p. 716-23.

10. Harsha DW, Bray GA. Body composition and childhood obesity. Endocr Metab Clin 1996; 25:871-85.

11. Rosner B, Prineas R, Loggie J, Daniels SR. Percentiles for body mass index in U.S. children 5 to 17 years of age. J Pediatr 1998; 132:211-22.

12. CDC. Body mass index-for-age. BMI is used differently with children than it is with adults. CDC home/search/health topics A-Z 2 2001; Mar 16:1-6.

13. Karlberg J, He Q. Prevalence and definition of childhood obesity. JPOG 1999; 7:21-3.

14. Yap MA, Tan WL. Factors associated with obesity in primary-school children in Singapore. Asia Pacific J Clin Nutr 1994; 3:65-8.

15. Satoto, Karjati S, Darmojo B, Tjokroprawiro A, Kodyat BA. Kegemukan, obesitas dan penyakit degeneratif: epidemiologi dan strategi penanggulangan. Widyakarya
Nasional Pangan dan Gizi VI. Serpong 17-20 Februari 1998: 787- 808.

16. Gortmaker SL, Must A, Sobol AM, Peterson K. Television viewing as a cause of increasing obesity among children in the United States, 1986-1990. Arch Pediatr Adolesc Med 1996; 150:356-62.

17. Whitaker RC, Wright JA, Pepe MS, Siedel KD, Dietz WH. Predicting obesity in young adulthood from childhood and parental obesity. N Engl J Med 1997; 337:869-73.

18. Vanitallia TB. Predicting obesity in children. Nutrition Reviews 1998; 56: 154-5.

19. Dietz WH Critical periods in childhood for the development of obesity. Am J Clin Nutr 1994; 59: 955-9.

20. Latief A, Tumbelaka AR, Chair I, et all. Beberapa cara pengukuran. In: Matondang CS, Wahidiyat I, Sastroasmoro S, editors. Diagnosis fisis pada anak. 2 nd ed . Jakarta. PT Sagung Seto 2000. p. 173-82.

21. Kodyat B, Minarto, Raoef R, Sianturi G, Iryanis. Status konsumsi gizi di Indonesia: Analisis data survei konsumsi gizi tahun 1995. Gizi Indon 1996. p. 40-50.

22. Reilly JJ, Dorosty AR. Epidemic of obesity in UK children. Lancet 1999;354:1874-5.

23. Maynard LM, Wisemandle W, Roche AF, et al. Childhood Body composition in relation to body mass index. Pediatrics 2001;107:344-50.

24. Hernandez, Gortmaker SL, Colditz GA, Peterson KE, Laird NM, Cabrera SP. Association of obesity with physical activity, television programs and other forms of video viewing among children in Mexico city. Int Journal of obesity $1999 ; 23: 845-54$.

25. Faith MS, Berman N, Heo M, et al. Effect contingent televion on physical activity and television viewing in obese children. Pediatrics 2001; 107:1043-8. 